\title{
HUBUNGAN PENDIDIKAN DALAM KELUARGA DENGAN HASIL BELAJAR PKn SISWA KELAS XI SMA NEGERI SIPAHUTAR TAPUT I T.P 2021/2022
}

\author{
Dewi Lestari Pardede \\ Sekolah Tinggi Ilmu Ekonomi Medan \\ Email:dewipardede1991@gmail.com
}

\begin{abstract}
ABSTRAK
Jenis penelitian ini adalah penelitian korelasional. Penelitian ini digunakan untuk membuktikan ada atau tidaknya hubungan masalah yang diteliti dan melaksanakan metode dokumentasi, peneliti mengambil data hasil belajar nilai PKn pada semester I kelas XI SMA NEGERI SIPAHUTAR TAPUT yaitu berupa Daftar Kumpulan Nilai (DKN). Kecenderungan Pendidikan Dalam Keluarga Siswa Kelas XI SMA NEGERI SIPAHUTAR TAPUT Semester I T.P 2020/2021 adalah kategori sangat tinggi (32,5\%). Kecenderungan Hasil Belajar PKn Siswa Kelas XI SMA NEGERI SIPAHUTAR TAPUT Semester I T.P 2020/2021 adalah dengan sangat tinggi (30\%). Ada hubungan yang signifikan antara Pendidikan Dalam Keluarga Dengan Hasil Belajar PKn Siswa Kelas XI SMA NEGERI SIPAHUTAR TAPUT Semester I T.P 2020/2021, hal ini terbukti karena $t_{\text {hitung }}>t_{\text {tabel }}(23,46>1,684)$.

Kata Kunci: Pendidikan, Keluarga, Hasil Belajar.
\end{abstract}

\begin{abstract}
This type of research is correlational research. This study was used to prove whether or not there was a relationship between the problems studied and implementing the documentation method. The researcher took data on the results of Civics learning outcomes in the first semester of class XI SMA NEGERI SIPAHUTAR TAPUT in the form of a List of Values (DKN). Tendency of Education in Families of Class XI SMA NEGERI SIPAHUTAR TAPUT Semester I T.P 2020/2021 is a very high category (32.5\%). The trend of Civics Learning Outcomes for Class XI SMA NEGERI SIPAHUTAR TAPUT Semester I T.P 2020/2021 is very high (30\%). There is a significant relationship between Family Education and Civics Learning Outcomes for Class XI SMA NEGERI SIPAHUTAR TAPUT Semester I T.P 2020/2021, this is proven because tcount $>$ ttable $(23.46>1.684)$.

Keywords: Education, Family, Learning Outcomes

\section{PENDAHULUAN}

Sistem pendidikan memberikan suatu upaya dalam mendewasakan pikiran dan sikap siswa dalam pembelajaran. Pendidikan adalah suatu

tindakan yang mengupayakan segala pelatian berupa bimbingan untuk perubahan peserta didik dalam belajar mengajar di dalam kelas. Hal ini dilakuka untuk mengembangkan
\end{abstract}

p-ISSN 2648-8600

e-ISSN 2745-410X

Volume 4 Nomor 2 Desember 2021 
kecerdasaan anak bangsa dari dini sehingga mampu memberikan penyelesaian dari masalah yang dihadapi seperti pemecahan masalah dalam hidup. Disatu pihak pendidikan mempersiapkan peserta didik untuk menjadi manusia dengan perilaku yang sesuai dengan nilai, norma, dan peraturan yang berlaku di masyarakat. Peserta didik harus harus mematuhi falsafah hidup yang dianut oleh bangsa dan negaranya. Pendidikan juga merupakan proses interaksi yang mendorong terjadinya belajar. Belajar sendiri merupakan proses perubahan dalam perilaku, pengetahuan, serta sikap. Proses belajar mengajar ditandai dengan adanya pemberian stimulus yang diberikan kepada anak yaitu dapat berupa latihan, pengalaman, motivasi, bimbingan, serta layanan. Selain guru di sekolah, keluarga juga memiliki kewajiban yang sama dalam memberikan stimulus tersebut. Keluarga merupakan salah satu faktor yang berperan dalam keberhasilan belajar anak. Salah satu defenisi "keluarga" dalam Kamus Besar Bahasa Indonesia (2011:321) adalah, "ibu bapak dengan anak-anaknya". Keluarga dijadikan sebagai unit pelayanan karena masalah kesehatan keluarga saling berkaitan dan saling mempengaruhi antara sesama keluarga dan akan mempengaruhi pula keluargakeluarga yang ada disekitarnya atau dalam konteks yang luas berpengaruh terhadap negara.

Pendidikan dalam keluarga terhadap anak, dapat direalisasikan dalam bentuk perhatian dan keperdulian terhadap anak yaitu dengan menyediakan sarana belajar siswa, memberikan motivasi, memberikan bimbingan, mengingatkan anak-anak terhadap kewajibannya, mengingatkan anak-anak terhadap kebutuhan mereka dan sebagainya. Dengan adanya perhatian dan keprdulian dari orang tua maka akan mempengaruhi tingkah laku anak yang akan berpengaruh pula terhadap hasil belajar yang diharapkan. Seharusnya orang tua dapat berperan dalam menciptakan suasana yang mendorong anak senang belajar, yaitu dengan memberikan keamanan dan kebebasan psikologis pada anak yang akan mendorong terciptanya komunikasi yang aktif antara orang tua dengan anaknya. Komunikasi dan koordinasi antara orang tua dan pihak sekolah juga perlu dibina dan dijaga agar keduanya terlibat dalam pendidikan siswa dan diharapkan dapat meningkatkan hasil belajar siswa.

Lingkungan lain yang tidak kalah pentingnya dari lingkungan fisik adalah lingkungan sosial, yang mana lingkungan pergaulan antara siswa, yakni lingkungan pergaulan antara pendidik dengan peserta didik, peserta didik dengan teman sebaya, peserta dengan lingkungan keluarga yang terlibat dalam intraksi pendidikan. Siswa yang memiliki bekal atau input memadai terhadap mata pelajaran PKn, maka akan memiliki peluang lebih besar dalam pencapaian hasil belajar dibanding dengan siswa yang tidak miliki bekal atau input terhadap mata pelajaran PKn tersebut. Atau dengan kata lain, keberhasilan hasil belajar siswa atau output (prestasi belajar siswa) banyak ditentukan oleh input
p-ISSN 2648-8600

e-ISSN 2745-410X

Volume 4 Nomor 2 Desember 2021 
yang dimiliki oleh siswa serta proses pembelajaran.

Motivasi adalah dorongan yang ada dalam diri siswa yang menyebabkan ada tingkah laku kearah suatu tujuan tertentu. Motivasi juga berarti penggerak tingkah laku kearah tujuan dengan didasari oleh adanya suatu kebutuhan. Dari pengertian motivasi tersebut tampak tiga hal, yaitu : 1) motivasi dimulai dengan satu perubahan dari dalam diri siswa, 2) motivasi itu ditandai oleh dorongan afektif yang kadang tampak dan sulit diamati, 3) motivasi ditandai oleh reaksi-reaksi untuk mencapai tujuan.

SMA NEGERI SIPAHUTAR TAPUT adalah salah satu diantara sekian SMA yang ada di Kabupaten Humbang Hasundutan. Berdasarkan hasil wawancara yang saya laksanakan dengan pihak sekolah bahwa di SMA NEGERI SIPAHUTAR TAPUT orang tua/wali muridnya ada sebagian yang sibuk di luar rumah, ekonominya lemah, keadaan rohani dan jasmani orang tua terganggu, keluarganya tidak utuh, kurangnya kesadaran orang tua untuk memperhatikan anaknya sehingga otomatis untuk memperhatikan putra-putrinya kurang maksimal bahkan ada yang kurang perhatian sama sekali. Dalam kaitan ini maka nampak ada kelalaian orang tua melakukan kewajibannya dengan kenyataan di dalam praktek secara empiris. Hal ini menjadi menarik perhatian penulis untuk melakukan penelitian lebih lanjut Apakah ada hubungan antara pendidikan dalam keluarga dengan hasil belajar anak atau siswa.

p-ISSN 2648-8600

e-ISSN 2745-410X

Volume 4 Nomor 2 Desember 2021

\section{TINJAUN PUSTAKA}

\section{A. Kajian Teoritis}

1. Hakekat Belajar

Sistem pembelajaran akan menjadi rutinitas belajar dari dini untuk anak sebab belajar merupakan metode yang tiada henti dilakukan oleh manusia. Belajar tidak mengenal batas usia maupun waktu karena belajar dapat dilakukan distuasi formal dan non formal. Belajar akan di peroleh seseorang seacara alami ketika melakukan suatu kegiatan seperti mencuci piring atau belajar berbicara kepada pada waktu kecil.

Perkembangan waktu dan usia akan menuntun seseorang untuk belajar lebih baik dengan memasuki dunia pendidikan dari TK, SD, SMP, SMA, dan Perguruan Tinggi. Hal ini kan memberikan pengalaman dalam memahami pengetahuan secara kritis dan inovatif. Menurut Purwanto (2011:38) menyatakan bahwa : "Belajar merupakan proses dalam diri individu yang berinteraksi dengan lingkungan untuk mendapatkan perubahan dalam perilakunya".

Morgan dan Purwanto, (2014:84) mengatakan , belajar akan mengalami perubahan baik tingkah laku maupun pikiran berdasarkan pengalaman yang didapat dalam kehidupan.

Anurrahman dan Abdilla, (2012:35), berkata, belajar merupakan perkembangan kognitif, afektif, dan psikomotorik yang di dapat dari usaha sadar dalam mendapatkan pengalaman belajar. 
Sedangkan, Slameto (2013:2) mengatakan belajar merupakan perubahan sikap akibat dari pengaruh lingkungan atau interaksi dengan manusia lainnya.

Dari beberapa pendapat yang dikemukakan oleh para ahli di atas maka peneliti dapat menyimpulkan bahwa belajar adalah Suatu proses perubahan dalam diri manusia yang tampak dalam perubahan tingkah laku seperti kebiasaan, pengetahuan, sikap, keterampilan dan daya pikir.

\section{Pengertian Hasil Belajar}

Menurut Mudjiono (2011:5) menyatakan bahwa : "Hasil belajar merupakan hasil dari suatu interaksi tindak belajar dan tindak mengajar. Menurut Sudjana (2011:22) menyatakan bahwa : "Hasil belajar adalah kemampuan-kemampuan yang dimiliki siswa setelah dia menerima pengalaman belajar".

Dari beberapa pendapat yang dikemukakan oleh para ahli di atas maka peneliti dapat menyimpulkan bahwa keberhasilan belajar bukanlah semata-mata keberhasilan dari segi kognitif, tetapi mesti melumat aspekaspek lain, seperti aspek afektif dan aspek psikomotorik.

\section{Faktor-Faktor Yang Mempengaruhi Hasil Belajar}

Faktor-faktor

yang

mempengaruhi hasil belajar banyak jenisnya, tapi dapat digolongkan menjadi dua golongan saja, yaitu faktor internal dan faktor eksternal. Menurut Slameto (2013:54) Faktor-faktor yang mempengaruhi hasil belajar tersebut, yaitu :

1. Faktor internal a. Faktor jasmaniah yang terdiri dari :

1) Faktor kesehatan Sehat berarti dalam keadaan baik segenap badan beserta bagian- bagiannya/bebas dari penyakit. Kesehatan adalah keadaan atau hal sehat. Keadaan seseorang berpengaruh terhadap belajarnya. Proses belajar seseorang akan terganggu jika kesehatan seseorang terganggu, selain itu juga ia akan cepat lelah, kurang bersemangat, mudah pusing, ngantuk jika badannya lemah, kurang darah ataupun ada gangguangangguan/kelainankelainan fungsi alat inderanya atau tubuhnya.

2) Cacat Tubuh

Cacat tubuh merupakan ketidaksempurnaan dari salah satu anggota tubuh. Hal ini dapat berupa : mengalami kebutaan, tuli, dan lumpuh.

b. Faktor Psikologis, yang terdiri dari :

1) Inteligensi

Pemberian intelegensi dengan penyesuaian diri terhadap lingkungan yang baru sehingga akan sangat efektif dalam pembentukan karakter. Pelatihan dasar kemampuan otak akan membantu dari pengembangan kemampuan 
anak seperti permainan puzzle.

2) Perhatian

Perhatian menurut Gazali adalah keaktifan jiwa yang dipertinggi, jiwa itu pun semata-mata tertuju kepada objek (benda/hal) atau sekumpulan objek. Motif

Motif erta sekali hubungannya dengan tujuan yang akan dicapai.

3) Kesiapan

Kesiapan adalah kesediaan untuk memberi response tau bereaksi. Kesediaan itu timbul dari dalam diri sesorang dan juga berhubungan dengan kematangan, karena kematangan berarti kesiapan untuk melaksanakan kecakapan.

4) Bakat

Bakat adalah kemampuan untuk belajar dimiliki anak dari dini tanpa disadarinya. Hal ini akan terlihat dari kemampuan anak yang berbeda dengan teman seusianya atau dengan kecepatan atau ketangkasan anak dalam memecahkan masalah.

c. Faktor Kelelahan

Kelelahan pada seseorang walaupun sulit dapat dibedakan menjadi dua macam, yaitu kelelahan jasmani dan kelelahan rohani (bersifat psikis).
Kelelahan rohjani dapat dilihat dengan adanya kelesuan dan kebosanan, sehingga minat dan dorongan untuk menghasilkan sesuatu hilang.

2. Faktor Eksternal

Faktor ekstern dibagi menjadi 3 faktor yaitu :

a. Faktor Keluarga Siswa yang belajar akan menerima pengaruh dari keluarga berupa : cara orang tua mendidik, relasi antara anggota keluarga, suasana rumah tangga, dan keadaan ekonomi keluarga.

b. Faktor

Sekolah

Faktor sekolah yang mempengaruhi belajar ini mencakup metode mengajar, kurikulum, relasi guru dengan siswa, relasi siswa dngan siswa, disiplin sekolah, standar pelajaran, keadaan gedung, metode belajar dan tugas rumah.

c. Faktor Masyarakat

Masyarakat merupakan faktor ekstern yang juga berpengaruh terhadap belajar siswa. Pengaruh itu terjadi karena keberadaannya siswa dalam masyarakat diantaranya adalah kegiatan siswa dalam masyarakat, massa media, teman bergaul dan bentuk kehidupan 
masyarakat, yang semuanya mempengaruhi belajar.

Selanjutnya Menurut Bloom, dkk dalam Aunurrahman (2012:49) Penggolongan atau tingkatan jenis perilaku yang mempengaruhi hasil belajar terdiri dari tiga ranah atau kawasan, yaitu :

1. Ranah kognitif terdiri dari enam jenis, yaitu :

a. Pengetahuan, mencakup kemampuan ingatan tentang hal-hal yang telah dipelajari dan tersimpan di dalam ingatan.

b. Pemahaman, mencakup kemampuan menangkap sari dan makna hal-hal yang dipelajari.

c. Penerapan, mencakup kemampuan menerapkan metode, kaidah untuk menghadapi masalah yang nyata dan baru.

d. Analisis, mencakup kemampuan merinci suatu kesatuan ke dalam bagianbagian sehingga struktur keseluruhan dapat dipahami dengan baik.

e. Sintesis, mencakup kemampuan membentuk suatu pola baru, misalnya tampak di dalam kemampuan menyusun suatu program kerja.

f. Evaluasi, mencakup kemampuan membentuk pendapat tentang beberapahal berdasarkan kriteria tertentu.
2. Ranah Afektif terdiri dari lima jenis perilaku, yaitu:

a. Penerimaan, yang mencakup kepekaan tentang hal-hal tertentu dan kesediaan memperhatikan hal tersebut.

b. Partisipasi, yang mencakup kerelaan, kesediaan, memperhatikan dan berpartisipasi dalam suatu kegiatan.

c. Penilaian dan penentuan sikap yang mencakup penerimaan terhadap suatu nilai, menghargai, mengakui, dan meneetukan sikap.

d. Organisasi, yang mencakup kemampuan membentuk kemampuan membentuk suatu sistem nilai sebagai pedoman dan pegangan hidup.

e. Pembentukan pola hidup, yang mencakup kemampuan menghayati nilai,dan membentuknya menjadi pola nilai kehidupan pribadi.

3. Ranah psikomotorik terdiri dari tujuh perilaku, yaitu :

a. Persepsi, yang mencakup mendeskripsikan sesuatu secara khusus dan menyadari adnya perbedaan antara sesuatu tersebut.

b. Kesiapan, yang mencakup kemampuan menempatkan diri dalam suatu keadaan dimana akan terjadisuatu gerakan atau rangkaian 
gerakan, kemampuan ini mencakup aktivitas jasmani dan rahani (mental).

c. Gerakan terbimbing, mencakup kemampuan melakukan gerakan sesuai contoh atau gerakan peniruan.

d. Gerakan terbiasa, mencakup kemampuan melakukan gerakangerakan tanpa contoh.

e. Gerakan kompleks, yang mencakup kemampuan melakukan gerakan atau keterampilan yang terdiri dari banyak tahap secara lancar, efisien, dan tepat.

f. Penyesuaian pola gerakan, yang mencakup kemampuan mengadakan perubahan dan penyesuaian pola gerak-gerik dengan persyaratan khusus yang berlaku.

g. Kreativitas, mencakup kemampuan melahirkan pola-pola gerak-gerik yang baru atas prakarsa sendiri.

Dari beberapa pendapat yang dikemukakan oleh para ahli di atas maka peneliti dapat menyimpulkan bahwa faktor-faktor dan tingkatan jenis perilaku yang mempengaruhi hasil belajar sangat erat kaitannya dengan hasil hasil belajar. hasil belajar merupakan daya penggerak dan pendorong dari dalam maupun dari luar diri siswa yang dapat menimbulkan kegiatan belajar sehingga tujuan yang dikehendaki oleh siswa dapat tercapai yang mencerminkan adanya kebutuhan untuk belajar, adanya keinginan berhasil, adanya keinginan untuk mencapai kesuksesan atau menghindari kegagalan, adanya keinginan untuk berperestasidan adanya suatu usaha untuk mempengaruhi perilaku seseorang agar mengarah pada tujuan yang diinginkan.

Untuk mencapai perubahan yang diharapkan, baik perubahn pada aspek atau ranah kognitif, afektif maupun psikomotorik, maka belajar hendaknya memperhatikan secara sungguh-sungguh beberapa prinsip yang dapat mendukung terwujudnya hasil belajar yang diinginkan.

\section{Pengertian Pendidikan Dalam Keluarga}

Kedudukan dalam keluarga menjadi bagian utama dalam karakter anak. Pendidikan yang diperoleh anak adalah keluarga karena orang yang berperan dekat dengan mereka yaitu ornagtua dan sanak saudara.Sedangkan yang utama adalah anak didik berada di keluarga yang paling lama waktunya dibandingkan pada lembaga pendidikan yang lain. dengan demikian, keluarga merupakan lembaga pendidikan yang paling besar. Oleh karena itulah lembaga pendidikan keluarga dapat dikatakan sebagai lembaga pendidikan yang pertama dan utama.

Menurut Surya $(2010: 41)$
"Pendidikan Dalam Keluarga
merupakan lembaga pendidikan yang
sempurna sifat dan wujudnya untuk
melangsungkan kearah pembentukan
pribadi yang utuh".
Menurut Dewantara dalam
Surya (2010:41) "Pendidikan Dalam

p-ISSN 2648-8600

e-ISSN 2745-410X

Volume 4 Nomor 2 Desember 2021 
Keluarga merupakan tempat yang sebaik-baiknya untuk melakukan pendidikan orang-seorang atau pendidikan secara individu maupun pendidikan sosial".

Dari beberapa pendapat yang dikemukakan oleh para ahli di atas maka peneliti dapat menyimpulkan bahwa pendidikan dalam keluarga merupakan pusat pendidikan yang sangat penting dan sangat mempengaruhi pola hidup, berpikir dan bergaul anak, sehingga peran orang tua atau anggota keluarga sangat menentukan karateristik dan kepribadian anak.

\section{Bentuk-Bentuk Pendidikan \\ Dalam Keluarga}

Lingkungan

keluarga

merupakan lingkungan pendidikan yang pertama, karena dalam lingkungan inilah anak pertama-tama mendapatkan bimbingan dari orang tua, karena sebagian besar dari kehidupan anak adalah di dalam keluarga, Dengan demikian jelaslah bahwa orang yang pertama dan utama bertanggung jawab terhadap kelangsungan hidup dan pendidikan anak adalah orang tua. Tanggung jawab pendidikan terletak di tangan kedua orang tua dan tidak bisa dipikulkan kepada orang lain karena dia adalah darah dagingnya, kecuali berbagai keterbatasan kedua orang tua ini.

Sedangkang menurut Masnur (2011:93) Bentuk-bentuk pendidikan dalam keluarga adalah sebagai berikut :

1. Menanamkan Nilai Kerukunan

Kerukunan salah satu perwujudan budi pekerti.
Orang yang miliki budi pekerti luhur tentu lebih menghargai kerukunan dan kebersamaan daripada perpecahaan.

2. Menanamkan Nilai Ketakawaan Dan Keimanan

Seseorang yang memiliki ketakwaan dan keimanan yang benar dan mendasar terlepas dari apa agamanya tertentu akan memwujudkannya dalam perilaku dirinya.

3. Menanamkan Nilai Toleransi.

Nilai toleransi adalah mau memperhatikan sesamanya. Dalam keluarga nilai toleransi dapat ditanamkan melalui proses saling memperhatikan dan saling memahami antaranggota keluarga.

4. Mengembangkan kebiasaan sehat sedari dini

Kebiasaan sehat adalah kebiasaan-kebiasaan hidup yang sehat dan mengarah pada pembangunan diri lebih baik dari sekarang.

Dari beberapa pendapat yang dikemukakan oleh para ahli di atas maka peneliti dapat menyimpulkan bahwa bentuk-bentuk pendidikan dalam keluarga sangat berpengaruh bagi pembentukan kepribadian anak, dan juga menjadi tolak ukur bagi keberhasilan belajar anak.
p-ISSN 2648-8600

e-ISSN 2745-410X

Volume 4 Nomor 2 Desember 2021 


\section{Faktor-Faktor Yang}

Mempengaruhi Pendidikan

DalamKeluarga

Menurut Slameto (2013:60)

Faktor-faktor yang mempengaruhi pendidikan dalam keluarga adalah sebagai berikut :

1. Cara Orang Tua Mendidik

Keluarga sebagai lembaga pendidikan yang pertama dan utama adalah pendidikan yang ukuran kecil, tetapi bersifat menentukan pendidikan dalam ukuran besar yaitu bangsa, Negara, dan dunia. Oleh karena itu peranan keluarga dalam pendidikan anaknya sangatlah penting dan juga cara orang tua mendidik anaknya besar pengaruhnya terhadap belajar anaknya.

2. Suasana Rumah

Suasana rumah yang tenang dan tentaram juga sangat diperlukan agar anak dapat belajar dengan baik

3. Keadaan Ekonomi Keluarga Keadaan ekonomi keluarga erat hubungannya dengan belajar anak.

4. Latar Belakang Kebudayaan

Tingkat pendidikan atau kebiasaan di dalam keluarga mempengaruhi sikap anak dalam belajar. perlu ditanamkan kebiasaan-kebiasaan yang baik kepada anak, agar mendorong semangat anak dalam belajar.

\section{METODE PENELTIAN}

Adapun jenis penelitian ini adalah penelitian korelasional.
Penelitian ini digunakan untuk membuktikan ada atau tidaknya hubungan masalah yang diteliti dan melaksanakan metode dokumentasi, peneliti mengambil data hasil belajar nilai PKn pada semester I kelas XI SMA NEGERI SIPAHUTAR TAPUT yaitu berupa Daftar Kumpulan Nilai (DKN).

\section{HASIL DAN PEMBAHASAN}

Dengan menggunakan instrument penelitian diperoleh data variabel dan berdasarkan hasil pengolahan data akan diuraikan tentang deskripsi data, pengujian deskripsi data, pengujian persyaratan analisis, dan pengujian hipotesis.

\section{A. Deskripsi Data Hasil Penelitian}

1. Deskripsi Data Ubahan Pendidikan Dalam Keluarga (X)

Berdasarkan data yang diperoleh dari hasil penelitian dengan jumlah responden 40 orang, didapat skor tertinggi 75 dan skor terendah 40 , dengan rata-rata hitung $(\mathrm{M}=71,5)$ dan standar deviasi $(\mathrm{SD}=6,68)$. Distribusi frekuensi data ubahan pendidikan dalam keluarga $(\mathrm{X})$ dapat dilihat pada tabel 4.1.

Tabel 4.1. Distribusi Frekuensi Ubahan Pendidikan Dalam Keluarga (X)

\begin{tabular}{|c|c|c|c|c|}
\hline $\begin{array}{c}\mathrm{N} \\
\mathrm{o}\end{array}$ & $\begin{array}{c}\text { Rentang } \\
\text { an }\end{array}$ & $\begin{array}{c}\text { Frek. } \\
\text { Absol } \\
\text { ut }\end{array}$ & $\begin{array}{c}\text { Frek. Rela } \\
\text { tif }(\%)\end{array}$ & $\begin{array}{c}\text { Katego } \\
\text { ri }\end{array}$ \\
\hline 1 & $40-46$ & 12 & 30 & $\begin{array}{c}\text { Sangat } \\
\text { Tinggi }\end{array}$ \\
\hline 2 & $47-53$ & 7 & 17,5 & Tinggi \\
\hline 3 & $54-60$ & 6 & 15 & Cukup \\
\hline 4 & $61-67$ & 11 & 27,5 & rendah \\
\hline 5 & $68-75$ & 4 & 10 & $\begin{array}{c}\text { Sangat } \\
\text { rendah }\end{array}$ \\
\hline & Jumlah & 40 & $100 \%$ & \\
\hline
\end{tabular}


Berdasarkan tabel di atas dapat disimpulkan bahwa tingkat pendidikan dalam keluarga siswa kelas XI Semester I SMA Negeri 1 Onan Ganjang T.A 2015/2016 dikategorikan sangat tinggi (30\%).

2. Deskripsi Data Ubahan Hasil Belajar PKn Siswa (Y)

Berdasarkan data yang diperoleh dari hasil penelitian dengan jumlah responden 40 orang, didapat skor tertinggi 85, dan skor terendah 50, dengan rata-rata hitung $(M=59,52)$ dan standar deviasi ( $\mathrm{SD}=9,83)$. Distribusi frekuensi data ubahan hasil belajar PKn siswa (Y) dapat dilihat pada tabel 4.2.

Tabel 4.2. Distribusi Frekuensi Ubahan Hasil Belajar PKn Siswa (Y)

\begin{tabular}{|c|c|c|c|c|}
\hline $\begin{array}{c}\mathrm{N} \\
\mathrm{o}\end{array}$ & $\begin{array}{c}\text { Rentang } \\
\text { an }\end{array}$ & $\begin{array}{c}\text { Frek. } \\
\text { Absol } \\
\text { ut }\end{array}$ & $\begin{array}{c}\text { Frek. Rela } \\
\text { tif }(\%)\end{array}$ & $\begin{array}{c}\text { Katego } \\
\text { ri }\end{array}$ \\
\hline 1 & $50-56$ & 1 & 32,5 & $\begin{array}{c}\text { Sangat } \\
\text { Tinggi }\end{array}$ \\
\hline 2 & $57-63$ & 4 & 27,5 & Tinggi \\
\hline 3 & $64-70$ & 11 & 27,5 & Cukup \\
\hline 4 & $71-77$ & 11 & 10 & $\begin{array}{c}\text { Renda } \\
\text { h }\end{array}$ \\
\hline 5 & $78-85$ & 13 & 2,5 & $\begin{array}{c}\text { Sangat } \\
\text { Renda } \\
\text { h }\end{array}$ \\
\hline & Jumlah & 40 & $100 \%$ & \\
\hline
\end{tabular}

Berdasarkan tabel di atas dapat disimpulkan bahwa tingkat hasil belajar PKn siswa kelas XI Semester I SMA Negeri 1 Onan Ganjang T.A 2015/2016 dikategorikan sangat tinggi (32,5\%).

\section{B. Uji Persyaratan Analisis}

1. Uji Normalitas

Untuk normalitas variabel pendiikan dalam keluarga dilakukan dengan rumus chi-kuadrat $\left(\mathrm{X}^{2}\right)$. Maka syarat normal dipenuhi apabila $\mathrm{X}^{2}$ hitung $<\mathrm{X}^{2}$ tabel pada taraf signifikan a $=5 \%$, dengan derajat kebebasan $(\mathrm{dk}=$
40). Hasil uji normalitas data penelitian dapat dilihat pada tabel 4.3.

Tabel 4.3. Ringkasan Uji Normalitas Sebaran Data Penelitian

\begin{tabular}{|l|c|c|c|c|}
\hline $\begin{array}{l}\text { Variabel Pen } \\
\text { elitian }\end{array}$ & $\mathrm{dk}$ & $\begin{array}{c}\mathrm{X}^{2} \\
\text { hitung }\end{array}$ & $\begin{array}{c}\mathrm{X}^{2} \text { tabe } \\
1 \mathrm{a}=0, \\
05\end{array}$ & Kurva \\
\hline $\begin{array}{l}\text { Pendidikan } \\
\text { Dalam Kelua } \\
\text { rga (X) }\end{array}$ & 40 & 14,52 & 43,77 & Normal \\
\hline $\begin{array}{l}\text { Hasil Belajar } \\
(\mathrm{Y})\end{array}$ & 40 & 24,62 & 43,77 & Normal \\
\hline
\end{tabular}

Berdasarkan tabel di atas, uji normalitas dari setiap variabel diperoleh $\mathrm{X}^{2}$ hitung $<\mathrm{X}^{2}$ tabel pada taraf signifikan 5\%. Dengan demikian dapat disimpulkan bahwa distribusi data kedua variabel penelitian berdistribusi normal.

2. Uji Linieritas

Dalam penelitian ini terdapat dua variabel, yaitu ubahan bebas dan ubahan terikat. Dalam hal ini terdapat satu ubahan bebas yang diduga dapat mempengaruhi ubahan terikat. Oleh karena itu perlu diuji kelinieritasannya dengan menerapkan rumus regresi untuk linier $\mathrm{Y}=\mathrm{a}+\mathrm{bx}$. Dari hasil perhitungan diperoleh persamaan regresi sederhana $\mathrm{Y}=49,34+0,14 \mathrm{x}$ adalah linier pada taraf signifikan $5 \%$.

3. Uji Kecenderungan

a. Kecenderungan Variabel Pendidikan

Dalam Keluarga

Tabel 4.4 Kecenderungan

Pendidikan Dalam Keluarga

\begin{tabular}{|c|c|c|c|c|}
\hline $\begin{array}{c}\mathrm{K} \\
\text { el } \\
\text { as }\end{array}$ & Interval & Fo & Fr (\%) & Kategori \\
\hline 1 & $>67$ & 13 & 32,5 & $\begin{array}{c}\text { Sangat } \\
\text { Tinggi }\end{array}$ \\
\hline 2 & $61 \mathrm{~s} / \mathrm{d} 67$ & 7 & 17,5 & Tinggi \\
\hline 3 & $55 \mathrm{~s} / \mathrm{d} 60$ & 8 & 20 & Cukup \\
\hline 4 & $49 \mathrm{~s} / \mathrm{d} 55$ & 9 & 22,5 & Rendah \\
\hline 5 & $<48$ & 3 & 7,5 & $\begin{array}{c}\text { Sangat } \\
\text { Rendah }\end{array}$ \\
\hline
\end{tabular}




\begin{tabular}{|l|l|l|l|l|}
\hline & & 40 & 100 & \\
\hline
\end{tabular}

Berdasarkan tabel di atas dapat disimpulkan bahwa pendidikan dalam keluarga siswa kelas XI Semester I SMA Negeri 1 Onan Ganjang T.A 2015/2016 cenderung sangat tinggi $(32,5 \%)$.

b. Kecenderungan Hasil Belajar PKn Siswa

Tabel 4.5. Kecenderungan

Hasil Belajar PKn

\begin{tabular}{|c|c|c|c|c|}
\hline $\begin{array}{c}\mathrm{K} \\
\text { el } \\
\text { as }\end{array}$ & Interval & Fo & Fr (\%) & Kategori \\
\hline 1 & $>77$ & 12 & 30 & $\begin{array}{c}\text { Sangat } \\
\text { Tinggi }\end{array}$ \\
\hline 2 & $71 \mathrm{~s} / \mathrm{d} 76$ & 11 & 27,5 & Tinggi \\
\hline 3 & $65 \mathrm{~s} / \mathrm{d} 70$ & 10 & 25 & Cukup \\
\hline 4 & $59 \mathrm{~s} / \mathrm{d} 64$ & 5 & 12,5 & Rendah \\
\hline 5 & $<58$ & 2 & 5 & $\begin{array}{c}\text { Sangat } \\
\text { Rendah }\end{array}$ \\
\hline & & 40 & 100 & \\
\hline
\end{tabular}

Berdasarkan tabel di atas dapat disimpulkan bahwa hasil belajar PKn siswa kelas XI Semester I SMA Negeri 1 Onan Ganjang T.A 2015/2016 cenderung sangat tinggi (30\%).

4. Uji Hipotesis Penelitian

Untuk menguji hipotesis hubungan pendidikan dalam keluarga (X) dengan hasil belajar PKn siswa (Y) digunakan analisis korelasi dengan rumus product moment. Hasil analisis korelasi (rhitung) diperoleh sebesar 0,967 . Setelah dikonsultasikan dengan $\mathrm{r}_{\text {tabel }}=0,312$ pada taraf signifikan $5 \%$ dengan $\mathrm{N}=40$. Karna $\mathrm{r}_{\text {hitung }}>\mathrm{r}_{\text {tabel }}$ $(0,967>0,312)$, maka hal ini menunjukkan ada hubungan antara pendidikan dalam keluarga dengan hasil belajar PKn siswa kelas XI

p-ISSN 2648-8600

e-ISSN 2745-410X

Volume 4 Nomor 2 Desember 2021 semester I SMA Negeri 1 Onan Ganjang.

Dari hasil perhitungan diperoleh $t_{\text {hitung }}$ sebesar 23,46. Harga ini selanjutnya dikonsultasikan dengan $\mathrm{t}_{\text {tabel }}=1,684$ pada taraf signifikan $5 \%$ dengan $\mathrm{N}=40$. karna $\mathrm{t}_{\text {hitung }}>\mathrm{t}_{\text {tabel }}$ $(23,46>1,684)$, maka hal ini menunjukkan ada hubungan yang signifikan antara pendidikan dalam keluarga dengan hasil belajar PKn siswa Kelas XI SMA Negeri 1 Onan Ganjang Tahun Ajaran 2015/2016 dapat diterima kebenarannya .

\section{Pembahasan Hasil Penelitian}

Hasil penelitian menunjukkan : Ada hubungan yang signifikan antara pendidikan dalam keluarga dengan hasil belajar PKn siswa Kelas XI semester I SMA Negeri 1 Onan Ganjang Tahun Ajaran 2015/2016.

Lingkungan keluarga merupakan lingkungan pendidikan yang pertama, karena dalam lingkungan inilah anak pertama-tama mendapatkan bimbingan dari orang tua, karena sebagian besar dari kehidupan anak adalah di dalam keluarga, sehingga pendidikan sangat memberikan keuntungan dalam kehidupan karena faktor utama penentuanya yaitu hubungan dalam keluarga dan peran keluarga. Karakteristik yang diperoleh anak dari dini akan di dapatnya dari keluarga sebab yang utama dalam memperkenalkannya dalam dunia adalah keluarga. Didikan orangtua akan mempengarui dari mental anak dan perkembangan psikologis anak. Selain itu, keharmonisan dalam keluarga juga mencakup dalam perkembangan 
mental anak. Orangtua harus bisa bekerja sama dengan baik dalam menanamkan pembelajaran dini dengan efektif kepada anak, sehingga mempermudah anak dalam memahami setiap tindakan dan situasi yang berkembangan untuk dihadapinya.

\section{SIMPULAN}

\section{A. SIMPULAN}

Berdasarkan hasil analisis data dalam penelitian maka peneliti dapat mengambil kesimpulan sebagai berikut

1. Kecenderungan Pendidikan Dalam Keluarga Siswa Kelas XI Semester I SMA NEGERI SIPAHUTAR TAPUT T.P 2020/2021 adalah kategori sangat tinggi $(32,5 \%)$.

2. Kecenderungan Hasil Belajar PKn Siswa Kelas XI Semester I SMA NEGERI SIPAHUTAR TAPUT T.P 2020/2021 adalah dengan sangat tinggi (30\%).

3. Ada hubungan yang signifikan antara Pendidikan Dalam Keluarga Dengan Hasil Belajar PKn Siswa Kelas XI Semester I SMA NEGERI SIPAHUTAR TAPUT T.P 2020/2021, hal ini terbukti karena thitung $>t_{\text {tabel }}$ $(23,46>1,684)$.

\section{B. SARAN}

Berdasarkan kesimpulan di atas, ada beberapa saran yang perlu disampaikan penulis yang berhubungan dengan penelitian ini.

1. Sebaiknya orang tua harus berusaha memberikan dorongan kepada anaknya dalam upaya meningkatkan hasil belajar.
2. Hendaknya orang tua melengkapi fasilitas kepada anak untuk melibatkan diri dalam belajar yaitu dengan melakukan kegiatan yang merangsang atau mendorong serta menumbuhkan hasil belajar.

\section{DAFTAR PUSTAKA}

Arikunto, Suharsini, 2013, Prosedur Penelitian, Jakarta : Rineka Cipta.

Aunurrahman, 2012, Belajar Dan Pembelajaran, Bandung : Alfabeta.

Paradikma.

Dimyati, Drs. Mudjiono, 2011, Belajar

Dan Pembelajaran, Rineka Cipta.

Kaelan dan Zubaidi, 2010, Pendidikan

Kewarganegaraan, Yogyakarta :

Mohammad Suya, dkk , 2010, Landasan Pendidikan Menjadi Guru Yang Baik,

Indonesia.

Bogor : Penerbit Ghalia

Masnur Muslich, 2011, Pendidikan

Karakter PT. Bumi Aksara

Ngalim Puwanto, Psikologi

Pendidikan, 2010, Psikologi

Pendidikan Bandung :

$$
\text { Remaja Rosdakarya }
$$

Poerwadarminta, 2011, Kamus Umum

Bahasa Indonesia, Jakarta : Balai Pustaka.

Purwanto, 2013, Evaluasi Hasil Belajar, Jakarta : Rineka Cipta.

Slameto, 2013, Belajar dan faktorfaktor yang mempengaruhinya, Jakarta

Rineka Cipta.

Sri Lestari, 2012, Psikologi Keluarga, Jakarta : Kencana Prenada Media

Group. 